\title{
Giving Teaching Back to Education: Responding to the Disappearance of the Teacher
}

Gert J.J.Biesta, University of Luxembourg, Luxembourg

Email: gert.biesta@uni.lu

"Toute la pédagogie est un travail compliqué ... pour aider l'enfant à se dégager de la logique du caprice."

Philippe Meirieu (2008, p.13)

\section{Introduction: The Disappearance of Teaching and the Teacher}

This paper stems from a concern about a very particular development that has been going on in our educational institutions and our societies more generally, which is the disappearance of teaching and the concomitant disappearance of the teacher. ${ }^{1}$ It may sound odd to claim that teaching and teachers are disappearing, given that every day around the world millions of children and young people go to school, college or university, just as millions of their teachers do. To put some statistics to this claim: the US Census Bureau reported in 2011 that in the 2011-2012 school year 55.5 million children and young people will be enrolled in schools (from pre-kindergarten to $12^{\text {th }}$ grade), which is just over $19 \%$ of the entire population, and that they will be served by 7.2 million teachers, which is another 2.5\% (United States Census, 2011). To talk about the disappearance of teaching and the teacher in light of such figureswhich are likely to be roughly similar throughout the industrialised world - therefore requires some further elaboration.

What I have in mind here is not the actual disappearance of teaching and the teacher, but the disappearance — or at least the erosion — of a certain understanding of teaching and the teacher, an understanding in which it can be acknowledged that teachers are there to teach. Putting it this way does, however, raise a further difficulty because in recent years the argument that teachers should teach has been made most vociferously from conservative sides in an attempt to restore what might perhaps best be characterised as an authoritarian conception of teaching. Such a conception is orientated towards the idea that teaching is, and ultimately should be, a matter of control, so that the best and most effective teachers are the ones who are able to steer the whole educational process towards the production of pre-specified 'learning outcomes' or pre-defined identities, such as that of the 'good citizen' or the 'flexible lifelong learner.' The call for control—and for teachers to exert control—is often part of a wider moral panic about an alleged loss of authority in contemporary society, accompanied by the common 'reflex' that education is the key instrument for restoring authority (conveniently forgetting, of course, that authority is a relational matter and not something that one person can simply impose onto another)(see Bingham, 2009). 
To suggest that teaching can and should be reduced to matters of control, ends up in an uneducational extreme in which the fact that the child or student is never just the object of the teacher's actions but always also a subject in his or her own right is being denied for the sake of the creation of an abstract societal 'order.' The French educationalist Philippe Meirieu has, correctly in my view, characterised such an attitude towards education as infantile, as it operates on the assumption that the world-social and natural-simply is at our disposal and thus should obey to our whims rather than that we acknowledge that it exists independently from us (Meirieu, 2008, p.12). ${ }^{2}$ Yet my insistence that teachers should teach-and perhaps I can now add that teachers should be allowed to teach-is meant to respond to, and stay away from, another uneducational extreme, which is the reduction of all that matters educationally to questions of learning. This development, which I have analysed in detail in a number of publications (Biesta, 2004, 2006, 2010a, in press-a), is not so much an uneducational extreme because it would replace a teacher-centred conception of education with a child- or student-centred one-the simplistic opposition between conservative and progressive education that is often used by the former to misrepresent the latter-but because the learning question is fundamentally different from the educational question (which also means that the language of learning is fundamentally different from the language of education). ${ }^{3}$

The quickest way to express what is at stake here is to say that the point of education is never that children or students learn, but that they learn something, that they learn this for particular purposes, and that they learn this from someone. The problem with the language of learning and with the wider 'learnification' (Biesta, 2010a) of educational discourse is that it makes it far more difficult, if not impossible, to ask the crucial educational questions about content, purpose and relationships. Yet it is in relation to these dimensions, so I wish to suggest, that teaching matters and that teachers should teach and should be allowed to teach. And it is also in relation to these dimensions that the language of learning has eroded a meaningful understanding of teaching and the teacher. The aim of this paper, therefore, is to articulate the contours of a different-and as I will suggest: educational-understanding of teaching and the teacher, in order to be able, as I have put it in the title, to give teaching back to education, that is, to reclaim a proper place for teaching and the teacher in our educational endeavours. My ambition is to develop an argument for teaching and the teacher that is explicitly progressive, in order to counter conservative calls for a return of the teacher as a figure of (authoritarian) authority and control.

I will develop my thoughts in five steps. I start with a brief indication of the reasons why teaching — or a certain understanding of teaching - seems to have disappeared from the educational radar and seems to have been replaced with the idea of the facilitation of learning. In response to this I highlight that education, unlike learning, is always framed by a telos - that is, by a sense of purpose-which means that teachers always need to make judgements about what is desirable in relation to the different purposes that frame their practice. I will refer to this as the need for pragmatism in teaching. Against the idea that teaching is nothing but the facilitation of learning I will, in the third step, explore the crucial difference between the experience of 'learning from' and 'being taught by' and ask what it might mean for teachers to work with this distinction. This then brings me, in a fourth step, to questions about resistance and intrusion and about the need for the teacher to work with the student in the middle ground between self-destruction and world-destruction. In the fifth and final step I ask what these reflections mean for the question of knowledge in teaching. I conclude with a call for teachers to teach. 


\section{Learnification, Constructivism, and the Teacher as Facilitator}

I wish to suggest that the disappearance of a certain understanding of teaching and the teacher from the educational conversation is closely connected to, and at least partly the result of, what I have elsewhere referred to as the rise of a 'new language of learning' in education (see Biesta, 2004, 2006). The rise of this language can be seen in a number of discursive shifts that have occurred over the past twenty years or so (see also Haugsbakk and Nordkvelle, 2007), including the tendency to refer to teachers as facilitators of learning, to teaching as the creation of learning opportunities, to schools as learning environments, to students as learners and adults as adult learners, to the field of adult education as that of lifelong learning, and to the very idea of education as that of 'teachingandlearning'-which I deliberately write as one word, as this is how many people nowadays seem to use it. A rather extreme example of the 'learnification' (Biesta, 2010a) of educational discourse is the story of two primary schools in Sheffield that had to merge and, after their merger, not only came up with a new name for their school but also decided that they no longer wanted to call themselves a school because, so they argued, the word 'school' had such negative connotations with parents and children. Hence they decided to refer to themselves as Watercliffe Meadow: A Place for Learning. ${ }^{4}$

The rise of the new language of learning can be seen as the outcome of a number of partially related developments. One is the postmodern critique of authoritarian forms of education - a critique that, already in the 1980s, was perceived as the beginning of the end of education (for example, Giesecke, 1985). Another concerns the impact, particularly in the field of adult education, of neo-liberal ways of thinking, which has created the belief that individuals should take their own responsibility for their learning rather than that it being provided for by the state, a development that has established a 'new educational order' of lifelong learning (Field, 2000). And there is perhaps also the impact of the internet with its instant availability of a large volume of information, giving the impression that the school is increasingly becoming an outdated and superfluous institution because almost anything can be found and learned 'on line.' But the most important factor in the rise of the language of learning and its impact on educational practice has been the emergence of new theories of learning, particularly constructivist approaches. Constructivist theories have shifted the emphasis away from the activities of the teacher towards those of the student and have thus put those activities - often referred to as 'learning' (but see Biesta, in pressa) - on centre stage.

Although constructivism is first of all a theory of learning, the uptake of this theory in schools, colleges and universities has led to a change in practice that is often characterised as a shift 'from teaching to learning.' Barr and Tagg (1995) have made the even stronger claim that what is at stake is a Kuhnian paradigm shift from the 'Instruction Paradigm' to the 'Learning Paradigm.' The point of these phrases is not to suggest that under the instruction paradigm there was no interest in student learning whereas under the learning paradigm there is. The point for Barr and Tagg-and for many others who have made similar observations so as to create a present day 'common sense' - is that in the instruction paradigm the focus is on the transmission of content from the teacher to the student, whereas in the learning paradigm the focus is on the ways in which teachers can support and facilitate student learning. This is in line with Richardson's (2003) description of constructivist pedagogy as involving “the 
creation of classroom environments, activities, and methods that are grounded in a constructivist theory of learning, with goals that focus on individual students developing deep understandings in the subject matter of interest and habits of mind that aid in future learning” (p. 1627).

Claims and statements such as these clearly show how the language of learning, particularly in its constructivist form, has repositioned the teacher from someone who is at the heart of the educational process to one who literally stands at the sideline in order to facilitate the learning of his or her 'learners.' Some of the arguments that have contributed to the rise of the language of learning are not without reason-there is indeed a need to challenge authoritarian forms of education; the rise of the internet does raise the question as to what makes schools special; and, to a certain extent, it cannot be denied that people can only learn for themselves and others cannot do this for them (although this does not mean that there are no limits to constructivism; see Roth, 2011). However, the language of learning falls short as an educational language, precisely because, as mentioned, the point of education is never that students learn but that they learn something, for particular purposes and that they learn it from someone. The language of learning is unable to capture these dimensions partly because learning denotes a process that, in itself, is empty with regard to content and direction; and partly because learning, at least in the English language, is an individualistic and individualising term whereas the educational question-if, for the moment we want to phrase it in terms of learning-is always a matter of learning something from someone. ${ }^{5}$ From this angle it is just remarkable, if not shocking, how much policybut increasingly also research and practice-has adopted the empty language of learning to speak about education. Yet if this is indeed the only language available, then teachers end up being a kind of process-managers of empty and in themselves directionless learning processes. ${ }^{6}$

One could of course object that in practice what goes on in schools in most cases is actually very directed. But this shows precisely the point I wish to make: that the language of learning is not only utterly unhelpful in articulating such directions, but also makes the decision-making processes with regard to the direction of educational learning mostly invisible and inaccessible. In this sense one could say that the language of learning operates as an ideology, making what really goes on invisible and inaccessible.

\section{Teleology, Pragmatism, and Judgement}

The fundamental distinction between learning and education thus has to do with the fact that educational practices are always 'framed' by a particular purpose (or set of purposes; see below). They are constituted, in more technical terms, by their telos, and in this regard can be characterised as teleological practices. The question of purpose is in my view the most central and most fundamental educational question since it is only when we have a sense of what it is we want to achieve through our educational efforts - and 'achieve' needs to be understood in a broad sense, not in terms of total control - that it becomes possible to make meaningful decisions about the 'what' and the 'how' of our educational efforts, that is, decisions about contents and processes. This first of all means that all judgements in education are entirely pragmatic, that is, that any decisions about the content and form of education can only be made with reference to what it is one aims to achieve. This means that in education there is nothing that is desirable in itself. Whether education should be open, flexible, 
explorative, easy, personalised, child- or student-friendly, or whether it should be strict, outcome-focused, exam-driven, didactic, or difficult can only be decided in relation to the aims and ends of education.

There are two important provisos here. One is, as I will discuss in more detail below, that it is highly unlikely that education only 'works' in relation to a single aim or purpose, which means that there is the added difficulty of finding the right balance between the different aims and ends (also because a gain in one direction often implies a loss in another). The second proviso is that our educational activities and efforts can never be understood as neutral instruments with regard to what it is we aim to achieve. The means and ends in education are internally and intrinsically connected-which is a technical way for saying that students not only pick things up from what we say but also from how we say it and how we do it. Punishment, to use an extreme example, not only teaches students that certain behaviours are inappropriate, but also teaches them that force is sometimes justifiable-which means that the educational question is not simply whether punishment is an effective way to 'produce' certain 'outcomes,' but also whether punishment is an educationally desirable way to bring about such outcomes. This crude example also shows what is wrong with the language of effectiveness in education and why, instead, the focus needs to be on the explicitly normative question of good education (see also Biesta, 2010a).

The teleological character of education thus suggests quite a different position for the teacher, not as the one who is there to facilitate learning or to implement directives formulated elsewhere, but as the one who plays a central role in engaging with the question as to what is educationally desirable in each concrete situation, both with regard to the aims and with regard to the 'means' of education (and 'means' here needs to be understood in the broad, non-instrumental sense, that is, as the way in which education proceeds in terms of its contents, its processes and its relationships). This is a matter of judgement, not a matter of the execution of directives from elsewhere (something suggested in the English language with the popular idea that teaching is about the 'delivery' of the curriculum), be they from policy or from so-called 'evidence' (see Biesta, 2007, 2010b). There are, again, two additional points here.

Firstly, to make judgements about the aims of education requires engagement with the question as to what education is for. While this question is-and in democratic societies ought to be-a topic for on going discussion, it is important to see that the question of educational purpose is a multidimensional question, stemming from the fact that most if not all educational practices tend to function in relation to a number of different aims. I have found it helpful to make a distinction between three aims or, as I prefer to call them, three domains of educational purpose: qualification (roughly the domain of knowledge and skills); socialisation (the educational encounter with cultures and traditions); and subjectification (education's orientation towards children and students as subjects of action and responsibility, not objects of intervention and influence). If it is granted that education almost always functions in relation to these three domains - there is always something to learn, there is always the question of traditions and ways of being, and there is always the question of the person-then it means that the judgements teachers need to make about the aims of their activities are always 'composite' judgements, that is, judgements about priority and balance between the different domains of educational purpose. Given the fact that gain in relation to one dimension may often imply loss in relation to another-it is possible, for example, to push students towards the production of high exam scores, but this 
always comes at a (high) price-perhaps the most difficult task for the teacher is how to deal with such trade-offs.

Secondly, while the teacher is not the only one who should be engaged with questions about educational purpose, the teacher nonetheless plays a crucial role because at the end of the day judgements about what is educationally desirable can only be made in response to the concrete and always unique situations that emerge from the encounter between teachers and their students. What may be desirable in the abstract-for example the policy mantra that the education system is a crucial investment in the production of a flexible workforce-maybe entirely meaningless in the encounter with this particular student in this particular situation and under these particular circumstances. That is why any judgement about educational purpose is first and foremost 'of' the teacher. This is also the case because such judgements are not only about the aims of education but also about the means, that is, the ways in which education proceeds - and again judgements about the way to proceed are always concrete, situated and in that sense unique. To deny the teacher this role-as tends to happen in highly prescriptive top down curricula and teaching strategies that have particularly been 'popular' in England over the past decades-misses the point of what teaching really is about, unless, that is, one would be satisfied for teachers to operate as unresponsive robots that are supposed to intervene on equally unresponsive objects rather than to engage in educational encounters with real human subjects. ${ }^{7}$

Teleology implies pragmatism, and pragmatism requires judgement, and in precisely this way we can see how once we go beyond the language of learning and (re)turn to a language of education the teacher begins to reappear, first of all in terms of the teacher's responsibility for making situated judgements about the educational desirability of the means and ends of how education 'proceeds.' If this highlights one aspect of what it means for teachers to teach, I now wish to turn to a second dimension of this, which brings us in a different way back to the question and the language of learning.

\section{The Gift of Teaching}

While in one sense the idea of the teacher as (just) a facilitator of learning is a relatively recent idea that has emerged with the rise of the language of learning and particularly with constructivist ideas about learning, it is, on the other hand, an idea with a long pedigree going straight back to Greek philosophy, to Plato's dialogue Meno, to Socrates and to the so-called 'learning paradox. ${ }^{8}$ The learning paradox is the predicament, posed by Meno, as to how one can go looking for something when one doesn't know what one is looking for, and how one can recognise what one is looking for if one doesn't know it (Plato, trans. 2008). Socrates's way out of the learning paradox is to argue that all learning is a matter of recollection, and this is the main reason why he maintains that he has nothing to teach but is just acting as a midwife, bringing out what is already there. The idea of the teacher as a midwife-called the maieutic conception of teaching - has indeed some appeal, which probably explains why it keeps popping up in the educational literature. Part of its appeal is normative and has to do with the fact, as mentioned before, that teachers should not aim for total control of their students but should always encounter them as human subjects in their own right. And part of its appeal, also already mentioned, has to do with the fact that people can only learn for themselves and others cannot do this for them. Taken together these lines seem to suggest that we should neither want the teacher to teach, nor that it is really possible for the teacher to do so. 
But we shouldn't draw our conclusions too hastily, because when we look more carefully at Socrates we can already see that he is not just there to facilitate any kind of learning but that, through an extremely skilful process, he is trying to bring his students to very specific insights and understandings. Seen in this way, Socrates is actually an extremely skilful didactician, because he knows all too well that to just 'rub it in' is unlikely to convince his students about the things he wants to convince them of. We could even say that Socrates is actually a very manipulative teacher because he seems to be hiding - at least at the level of what he says but in a certain sense also through what he does - the very 'art' he is practicing. Sharon Todd (2003) has therefore likened Socrates to the perfect murderer, who "makes it appear that teaching has not taken place, who leaves the scene without a trace, and who, moreover, is convinced of his own innocence" (p.23). She notes, however, that by proclaiming his questions to be innocent, Socrates actually "obscures the fundamental structures of alteration and asymmetry that are present between teacher and student" (p. 25). To suggest that the teacher adds nothing to the situation, to suggest that the teacher has nothing to give but is just drawing out what is already there is, therefore, a misrepresentation of what teachers do and what teaching is about; a misrepresentation, moreover, that has contributed significantly to the erosion and disappearance of teaching and the teacher (particularly where teachers themselves have began to talk about their own work in this way; see Priestley, Biesta and Robinson, 2012).

Here, then, we touch upon another dimension of what it means for teachers to teach, which is to acknowledge that teaching is not about the repetition of what is already there but about bringing something new-and perhaps it is important to say: something radically new - to the situation. This is what Emmanuel Levinas (1969) has in mind when he wrote that "( $\mathrm{t}$ )eaching is not reducible to maieutics [but] comes from the exterior and brings me more than I contain” (p.51). In this way teaching can, and in my view should, thus be understood as a gift (see also Biesta, in press-b). Partly flippantly but partly also very seriously one could say that giving this gift is precisely the point of the school, so that rather than to think of the school as a place for learning - as in the case of Watercliffe Meadow or Ellsworth (2004) - we should think of it as a place for teaching. One can, after all, learn anywhere, but the gift of teaching is only 'available' in a very small number of places and the school is definitely one of them. This is not to suggest, of course, that teaching cannot happen in other places too, but I do think that it is important that we begin to understand the school (again) in terms of teaching, as that, and not learning, is what makes the school special and different from many other spaces and places.

To think of teaching as a gift does, of course, raise the question of what it means to give a gift; a theme that has become quite prominent in recent philosophical, sociological and educational literature, particularly in relation to the distinction between a gift and an exchange, that is, where the one receiving the gift feels the need to give something back (see Derrida, 1992a; Komter, 1996; Wimmer, 2001). Rather than to approach this question from the gift giver-that is the teacher-I have found it helpful, for a number of reasons (see Biesta, in press-b), to look at this from the side of the one receiving the gift of teaching, that is, the student. When we look at it from this angle we might say that there are two ways in which students might receive something from their teachers. They can-and this is perhaps the most popular expression in the context of the language of learning-learn from their teachers or they can, in a different and older language, be taught by their teachers. Is there a 
difference between 'learning from' and 'being taught by'? I think there is, and to appreciate this difference, in my view, is crucial.

While both phrases are about the relationship between students and their teachers, they do specify a radically different relational 'quality' between the two. When we learn from our teachers, we could say that we ultimately approach and use our teachers as a resource. The teacher here is structurally at the same level as a book, the internet or any other 'learning resource' in that when we learn from such resources we go to them with our questions in order to find (our) answers. We could say, therefore, that when we learn from our teachers we are in a very fundamental sense 'in control' of our learning and our engagement with our resources more generally. This is precisely where the experience of 'being taught' is a radically different one, because when we are being taught by someone, something enters our field of experience in a way that is fundamentally beyond our control. (Just think of situations where we would say —always in hindsight — that someone 'has really taught us something.') Such 'lessons' are often far more difficult to receive than the things we learn from others, because they enter us radically from the outside - they 'hit us,' we might sayand in a sense it is hard work to give such 'lessons' a place, to accommodate them (perhaps also in the literal sense of providing them with accommodation, that is, with a place where they can be). While we could say, therefore, that to 'learn from' puts the student in a position of mastery, to be 'taught by' positions the student more humbly vis-à-vis what comes to him or her; it appeals to a capacity for receptivity and perhaps even gratitude, rather than mastery.

Looking at the gift of teaching from this angle highlights something very important, which is that it is not within the power of the teacher to give this gift, but depends on the fragile interplay between the teacher and the student. Teachers can at most try and hope, but they cannot force the gift upon their students. Similarly, students can be open to the gift but they cannot force the teacher to give them this gift. A gift is, after all, (a) given. In this regard the gift is, as Derrida would call it, impossible, which doesn't mean that it is not possible but that it cannot be foreseen as a possibility (Derrida, 1992b, p.16), it cannot be demanded, predicted, calculated or produced, but comes when it arrives. Nonetheless it is crucial that teachers operate with an appreciation of the distinction between 'learning from' and 'being taught by,' with an appreciation of the distinction between themselves as a resource or, in one word, as a teacher.

\section{Resistance, Education, and the Middle Ground}

If teachers teach, or perhaps we should say: if they manage to teach, that is, if they manage to bring something new to the situation and if this newness manages in some way to 'arrive,' then it means that teaching in this sense is always an interruption of some kind (Biesta, 2009b) or, in the words of Jean-Luc Nancy (in a fascinating essay about his heart transplant), an intrusion (Nancy, 2000). Teaching 'works' with something that is strange from the perspective of the student, not because what is given/received is necessarily incomprehensible, but because it is something that comes from the outside or the 'exterior' (Levinas, 1969). From the perspective of the student teaching thus brings something that is strange, something that is not a projection of the student's own mind, but something that is radically and fundamentally other. The encounter with something that is other and strange-that is not of one's own making -is an encounter with something that offers resistance (and we could even say that it is an encounter with the very experience of resistance). Such 
an encounter, so I wish to suggest, is of crucial educational significance if it is granted that education is not a process of development of what is already 'inside' nor a process of adaptation to what comes from the 'outside,' but is an ongoing dialogue between 'self' and 'other' (in the widest sense of the word 'other') in which both are formed and transformed-a process through which we come 'into the world' (see Winter, 2011) and the world comes into us. I use 'dialogue' here not in the sense of a verbal exchange, but to denote a process in which there are interacting parties and where what is 'at stake' is for all parties to 'appear' (which precisely does not mean that they are not interrupted or intruded upon (see Biesta, 2006, chapter 1). A dialogue is therefore fundamentally different from a competition, where the orientation is for one of the parties to win, which means that the others automatically lose.

So what do we do when we encounter resistance? ${ }^{9}$ In theory there are three options. One is to try to overcome what resists us or offers us resistance. Here we try to impose our will upon the world, upon that which we encounter as other. This ultimately leads to a destruction of the very 'thing' that resists - either literally or in the form of a denial of the otherness and strangeness of what we encounter (and 'mastery' is one form in which this can occur). The second option, at the opposite end of the spectrum is to shy away from what resists us or offers us resistance. It is to withdraw ourselves from what is strange and other, not to engage with it, not to connect. If the first response ultimately results in a destruction of the world, the second response, so we might say, ultimately results in a destruction of the self, as the self withdraws from the world and therefore does not exist in any worldly way. That is, the self only exists for itself, but not for and with others. If the educational 'interest' is in the dialogue between self and world, we can see that both extremes-worlddestruction and self-destruction-fail to achieve the establishment of such a dialogue, the first because it destroys the conditions under which the self can come into the world (there is, after all, no world left); the second because the self stays with itself and never manages to really engage with the world. ${ }^{10}$ This suggests that the educational 'space' is located in the frustrating middle ground between worlddestruction and self-destruction-and I refer to this middle ground as 'frustrating' because it is here that we need to work 'through' that what resists us (rather than destroy it or destroy ourselves), we need to come to terms with it, rather than being allowed an easy way out (the way of destruction or the way of withdrawal).

If these ideas make sense, they suggest, first of all, that the experience of resistance is the point at which education in a sense only begins. This is not only so for the student, but also for the teacher because without the resistance of the child or student, they only appear as objects, but not as subjects in their own right. This not only means that without such resistance education becomes the monologue of the teacher; it also means that without the teacher education becomes the monologue of the student. The first observation brings us back to the uneducational ambition of teaching as total control; the second provides us with yet another way to indicate why the language of learning-which is ultimately a monological language-is not an educational language.

My reflections on the different ways in which we can respond to resistance also suggest yet another dimension of what it means to teach. If it is the case that the experience of resistance is the point at which education begins, then to teach means first of all to enter this experience into the educational situation - that is, to make the encounter between child and world possible, to 'stage' this encounter. It also means to 'allow' for the experience of resistance within this encounter, which means to actively look for opportunities to encounter and engage with resistance (both the resistance of 
the material world — think of the value of working with so-called 'resistant material'and the resistance of the social and human world). And it means, above all, to help the child or student to stay 'with' that which resists and to work 'through' it rather than against it; to help the child or student to endure the frustration of staying in the middle ground. ${ }^{11}$

For this to be possible it is also important that the school itself resists the all too facile demands from society to be effective and efficient, to gain total control over the educational process so as, in this (uneducational) sense, to become "perfect". It must, in other words, resist the call to become just a function of and thus be entirely functional for society. Here the original meaning of schole as leisure time, time not defined by the demands of any societal function, is worth revisiting - not so as to make school irrelevant for society but to allow the school to be properly educational, something it can only do if it allows for the openness and risk inherent in all education (see Biesta, in press-c).

\section{Evidence, Competence, or Wisdom?}

If these ideas begin to outline the contours of a different understanding of teaching one where teachers can do proper educational 'work' then the final point I wish to briefly touch upon has to do with the question of what teachers may need in order to teach. Here we enter the complex terrain of teacher education and teacher professional development. To refer to this terrain as 'complex' is not so much to highlight that questions about teacher education and teacher development have an exceptionally high level of theoretical complexity, but to indicate the increased political complexity of the discussion in this field. This is due to the fact that policy makers and politicians are increasingly beginning to see that their desire for total control over education not only requires control over the schools-which in some countries has been established to a high degree as a result of the combined effect of national curricula and teaching strategies, national standards and testing and examination procedures, and a tight system of inspection and accountability-but also requires control over the education, or in the lingo favoured by some politicians: the training, of teachers.

In the discussion about these issues we can see two main trends (see Biesta, in press-d). One, which is being pushed by certain sectors of the educational research community, stresses the need for teaching to become an evidence-based or evidenceinformed profession, where ultimately teachers only do that for which there exists positive scientific evidence that such interventions will produce the desired effects (for an overview and critical discussion see Biesta, 2007). The other trend, particularly strong in the discourses coming from policy makers at national, European and international levels, looks at the formation of teachers in terms of competencies, arguing that all teachers need to master all the competencies they need to conduct their work. In one sense it is difficult to argue against the idea that teachers should be competent, and there could even be some reason in the suggestion that teaching should be informed by insights from educational research; although the research that sees teaching as an intervention working towards the perfect production of certain pre-specified outcomes seriously misses the point of what I have suggested teaching is about. The problem with these lines of thought is that they miss what I have suggested to be at the very heart of teaching, which is the need for concrete situated judgements about what is educationally desirable, both with regard to the aims of education and with regard to its means. While some insights from research might feed into such judgements, they can never replace such judgements, particularly because in some 
cases the judgement might well go against available evidence. And while certain competencies may constitute a necessary condition for good teaching, they can never be a sufficient condition as there is always a need for judgement about which competencies should be utilised in each particular and unique educational situation.

This suggests that for teachers to be able to teach they need to be able to make judgements about what is educationally desirable, and the fact that what is at stake in such judgements is the question of desirability, highlights that such judgements are not merely technical judgements-not merely judgements about the 'how' of teaching - but ultimately always normative judgements, that is judgements about the 'why' of teaching. Such judgements, to use Aristotle's distinction, are not about teaching as poiesis, that is, as a process of production for which we need a capacity for judgement called 'techne,' but about teaching as praxis, that is, a process orientated towards the human good, for which we need a capacity for judgement called 'phronesis' or practical wisdom (see Aristotle, 1980). Such practical wisdom is not a skill or competence - and even less a matter of scientific evidence-but a quality or 'excellence' that permeates and characterises the whole person. This means that the question here is not how teachers can learn practical wisdom; the question rather is how they can become educationally wise. Aristotle's contention "that a young man [sic] of practical wisdom cannot be found" (p. 148) suggests that such wisdom comes with age or better: that it comes with experience and more specifically that it comes with the experience of engaging oneself in the exercise of such judgements. The

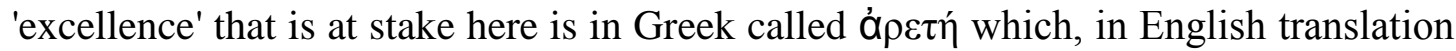
becomes 'virtue.' While we might say that the question of the formation of the teacher should be orientated towards becoming a 'virtuous' professional, it is perhaps more informative to suggest that the question of the formation of the teacher should be oriented towards a certain 'virtuosity' with regard to making concrete situated judgements about what is educationally desirable.

\section{Conclusions: Teachers Teach!}

Perhaps there is only one thing I should say in conclusion, and that is that teachers should teach, that they should be allowed to teach, and that they should have-and perhaps regain - the courage to teach. What I hope that my reflections have been able to show is not only why teaching has become so marginalised as it has been, but also what it might mean to teach and to do so in an educational way. With this I hope that a new light on some old ideas might help teachers not only in reclaiming their proper place in the educational 'order of things,' but also to resist conservative attempts to restore a kind of teaching that ultimately undermines the very education teaching should seek to make possible.

\footnotetext{
${ }^{1}$ I present this as a general concern and invite the readers to explore the extent to which my observations ring true with experiences in their contexts and settings. This paper is particularly informed by my experiences in a range of European countries and my familiarity with Continental traditions of educational theory and scholarship, albeit that some of the developments I will discusssuch as the turn towards 'learning' and away from 'education'—can be found in the wider international field of educational research, policy and practice.

${ }^{2}$ I return to the educational significance of the experience of resistance in encountering the otherness of the world below.

${ }^{3}$ Although the special issue to which this paper is a contribution focuses on the theme of 'the pedagogical call,' I will use the words 'pedagogy' and 'pedagogical' sparingly because I believe that there is a risk that the richness of these words in languages such as German and Dutch may get lost when the English words 'pedagogy' and 'pedagogical' are used to translate words such as 'Pädagogik'
} 
and 'pädagogisch' (German) and 'pedagogiek' and 'pedagogisch' (Dutch). On the difficulty of translating between Anglo-American and Continental traditions see also Biesta (2011). A further question in this regard concerns the language of 'curriculum', which over the past decades has become particularly influential in North America. Viewed from my European background the 'reconceptualisation' of curriculum studies (Pinar, Reynolds, Slattery, \& Taubman, 1995; Pinar 1998) appears to have moved the field into the direction of cultural studies and thus to questions of identity and social justice rather than in the direction of 'Pädagogik' and to questions of subjectivity and democracy. I note that this has perhaps resulted in a greater rift than the one between 'Didaktik' and curriculum (see Gundem \& Hopmann, 1998), by which I do not wish to pass any judgement about the respective merits of these developments.

${ }^{4}$ See http://en.wikipedia.org/wiki/Watercliffe_Meadow; accessed on 29 August 2012.

${ }^{5}$ Below I will argue that the better way to express what goes on in education is through the experience of 'being taught' rather than the idea of 'learning from.'

${ }^{6}$ This also means that a turn towards understanding education as a process-for example a process of discovery, a process of creativity, or a process of emergence-also misses the point of what education is about (see also Biesta, 2009a).

${ }^{7}$ I use the word 'intervene' here deliberately because I think that it is a fundamental mistake to think of education as an intervention. This language - which is prominent amongst researchers who try to establish what the most effective interventions for producing certain outcomes are-starts from the assumption that children and students are just 'response-objects,' not human subjects. For me education can only 'work'-if 'working' is the right term to begin with-because it is an encounter between subjects.

${ }^{8}$ Some authors do indeed conceive of Socrates and Plato as "the first constructivists in education" (Nola \& Irzik, 2005, p. 105) or, to be more precise, as the first ones enacting a constructivist pedagogy.

${ }^{9}$ My discussion of the role of resistance in education has been inspired by Meirieu (2008), although the detail of the ideas presented here is my own. Note that how I engage with resistance and its educational significance in what follows is entirely different from the sociology of resistance that can be found in the work of Giroux (for example Giroux, 1983).

${ }^{10}$ While the formulation may sound rather abstract, the experience it tries to describe is in my view extremely concrete and extremely common in the practice of teaching. Each time our students encounter a difficulty - or each time we confront our students with something that is difficult and strange - there are those who withdraw, who refuse to really engage with it, to be open to it, to let it in, and there are those who, often out of a sense of sheer frustration that what is difficult and strange 'escapes' them, put all their energy in bringing what resist under their control, whatever this might mean for the very 'thing' that offers them resistance.

${ }^{11}$ This is discussed in more detail in Biesta (2012), where I relate the question of the educational significance of the experience of resistance with the idea of the education of the will.

\section{References}

Aristotle. (1980). The Nicomachean ethics. Oxford: Oxford University Press.

Barr, R.B.\& Tagg, J. (1995). From teaching to learning: A new paradigm for undergraduate education. Change, 27(6), 13-25.

Biesta, G.J.J. (2004). Against learning. Reclaiming a language for education in an age of learning. Nordisk Pedagogik, 23, 70-82.

Biesta, G.J.J. (2006). Beyond learning. Democratic education for a human future. Boulder, Co.: Paradigm Publishers.

Biesta, G.J.J. (2007). Why 'what works’ won’t work. Evidence-based practice and the democratic deficit of educational research. Educational Theory, 57(1), 122. 
Biesta, G.J.J. (2009a). Theorising learning through complexity: An educational critique. Complicity, 6(1), 28-33.

Biesta, G.J.J. (2009b). What is at stake in a pedagogy of interruption? In T.E. Lewis, J.G.A. Grinberg, \& M. Laverty (Eds.). Philosophy of Education: Modern and Contemporary Ideas at Play (pp. 785-807). Dubuque, IA: Kendall/Hunt.

Biesta, G.J.J. (2010a). Good education in an age of measurement: Ethics, politics, democracy. Boulder, Co: Paradigm Publishers.

Biesta, G.J.J. (2010b). Why ‘what works’ still won’t work. From evidence-based education to value-based education. Studies in Philosophy and Education, 29(5), 491-503.

Biesta, G.J.J. (2011). Disciplines and theory in the academic study of education: A Comparative Analysis of the Anglo-American and Continental Construction of the Field. Pedagogy, Culture and Society, 19(2), 175-192.

Biesta, G.J.J. (2012). The educational significance of the experience of resistance: Schooling and the dialogue between child and world. Other Education: The Journal of Educational Alternatives, 1(1), 92-103.

Biesta, G.J.J. (in press-a). Interrupting the politics of learning, changing the discourse of education. Power and Education.

Biesta, G.J.J. (in press-b). Receiving the gift of teaching: From 'learning from' to 'being taught by.' Studies in Philosophy and Education. doi:10.1007/s11217012-9312-9

Biesta, G.J.J. (in press-c). The beautiful risk of education. Boulder, CO: Paradigm Publishers.

Biesta, G.J.J. (in press-d). Becoming educationally wise: Towards a virtue-based conception of teaching and teacher education. In A.-L. Østern, K.Smith, T. Ryghaug, T. Krüger \& M.B. Postholm (Eds.). Teacher education research between national identity and global trends. Trondheim: NAFOL.

Bingham, C. (2009). Authority is relational. Albany, NY: SUNY Press.

Derrida, J. (1992a). Given time: I. counterfeit money. (P. Kamuf, Trans.). Chicago: University of Chicago Press.

Derrida, J. (1992b). Force of law: The 'mystical foundation of authority.' In D. Cornell, M. Rosenfeld \& G. Carlson (Eds.), Deconstruction and the possibility of justice (pp.3-67). New York \& London: Routledge.

Ellsworth, E. (2004). Places of learning: Media, architecture, pedagogy. New York: Routledge.

Field, J. (2000). Lifelong learning and the new educational order. Stoke-on-Trent: Trentham Books. 
Giesecke, H. (1985). Das Ende der Erziehung. Stuttgart: Klett-Cotta.

Giroux, H.A. (1983). Theory and resistance in education: A pedagogy for the opposition. South Hadley, MA: Bergin \& Garvey.

Gundem, B.B. \& Hopmann, S. (Eds.). (1998). Didaktik and/or curriculum. New York: Peter Lang.

Haugsbakk, G. \& Nordkvelle, Y. (2007). The rhetoric of ICT and the new language of learning. A critical analysis of the use of ICT in the curricular field. European Educational Research Journal, 6(1), 1-12.

Komter, A. (1996). The gift: An interdisciplinary perspective. Amsterdam: Amsterdam University Press.

Levinas, E. (1969). Totality and infinity: An essay on exteriority. Pittsburgh: Duquesne University Press.

Meirieu, P. (2008). Pédagogie: Le devoir de résister. Nouvelle édition complétée 2008. Issy-les-Moulineaux: ESF éditeur.

Nancy, J.-L. (2000). L'intrus. Paris: Gallilée.

Nola, R., \& Irzik, G. (2005). Philosophy, science, education and culture. Dordrecht: Springer.

Priestley, M., Biesta, G.J.J. \& Robinson, S. (2012). Teacher beliefs and the achievement of agency. Manuscript in preparation. Stirling: University of Stirling. Retrieved from http://www.ioe.stir.ac.uk/events/tacc.php

Pinar, W.G. (Ed.). (1998). Contemporary curriculum Discourses. New York: Peter Lang.

Pinar, W.F., Reynolds, W.M., Slattery, P., \& Taubman, P.M. (1995). Understanding curriculum. New York: Peter Lang.

Plato. (2008). Meno. (B. Jowett, Trans.). Retrieved from http://www.gutenberg.org/files/1643/1643-h/1643-h.htm

Richardson, V. (2003). Constructivist pedagogy. Teachers College Record, 105(9), 1623-1640.

Roth, W.-M. (2011). Passability: At the limits of the constructivist metaphor. Dordrecht: Springer.

Todd, S. (2003). Learning from the other. Albany: SUNY Press.

United States Census Bureau, (2011, June). Profile America: Facts for features. Retrieved from http://www.census.gov/newsroom/releases/archives/ facts_for_features_special_editions/cb11-ff15.html 
Wimmer, M. (2001). The gift of 'Bildung.' In G.J.J. Biesta \& D. Egea-Kuehne (Eds.). Derrida \& Education (pp. 150-175). London/New York: Routledge.

Winter, P. (2011). Coming into the world, uniqueness, and the beautiful risk of education. An interview with Gert Biesta by Philip Winter. Studies in Philosophy and Education, 30(5), 537-542. 